Journal of Agricultural Sciences
(Tarim Bilimleri Dergisi)

\title{
The Effects of Gas Changes in the Shelter in the Summer Period on the Milk yield and Dry Material Consumption of Anatolian Water Buffalo (Bubalus bubalis)
}

\author{
Taşkın DEĞíRMENCIOĞLU ${ }^{a}$ (iD \\ ${ }^{a}$ Department of Milk and Fattening, Karacabey Vocational School, Bursa Uludag University, Bursa, TURKIYE \\ ARTICLE INFO \\ Research Article \\ Corresponding Author: Taşkın DEĞİRMENCİOĞLU, E-mail: taskin@uludag.edu.tr \\ Received: 30 June 2021 / Revised: 08 October 2021 / Accepted: 09 October 2021 / Online: 01 September 2022 \\ Cite this article \\ DEĞiRMENCIOĞLU T (2022). The Effects of Gas Changes in the Shelter in the Summer Period on the Milk yield and Dry Material Consumption of Anatolian Water Buffalo (Bubalus \\ bubalis). Journal of Agricultural Sciences (Tarim Bilimleri Dergisi), 28(3):511-517. DOI: 10.15832/ankutbd.960280
}

\section{ABSTRACT}

In this study, the effects of in-shelter gas concentration on milk yield and total dry matter intake (TDMI) of buffaloes during the spring and summer periods were investigated. The research was carried out in a shelter with 20 main Anatolian buffaloes between March and July. Values for temperature, relative humidity, air velocity, and $\mathrm{CH}_{4}, \mathrm{NH}_{3}$, and $\mathrm{CO}_{2}$ gases were recorded in the shelter. Data records were collected continuously for 24 hours for 4 days. Milk yield and DMI of buffaloes were also determined. As it was observed, higher air velocity in the house reduces the methane gas levels $(\mathrm{P}<0.01)$. The regression equation between milk yield and relative humidity was $\mathrm{Y}=6.011-0.03 \mathrm{RH}$ and showed a negative and low degree correlation. It was illustrated that TDMI varied between $11.00 \pm 0.12-13.20 \pm 0.06 \mathrm{~kg}$ during the summer. The difference observed between months in terms of feed intake was found to be statistically significant $(\mathrm{P}<0.05)$. Although the milk yield of water buffalo was low in March, it increased in April and May. However, there was a decrease in $\operatorname{DMI}(0.50 \mathrm{~kg} /$ day $)$ and milk yield $(264 \mathrm{~mL} /$ day $)$ for an increase of $+1{ }^{\circ} \mathrm{C}$ in air temperature. The recorded values for $\mathrm{CO}_{2}$ concentration in the buffalo shelter during the summer period varied between $620-1120 \mathrm{ppm}$. Considering the obtained results, $\mathrm{NH}_{3}$ and $\mathrm{CO}_{2}$ gas levels in the shelter were below the higher limits and can be considered as not dangerous for animal and human health. It was determined that regression equation between feed intake and temperature was $\mathrm{Y}=9.901+0.089 \mathrm{~T} * *$, regression coefficient was $\mathrm{R}^{2}=0.19$ and correlation coefficient was $\mathrm{r}=$ $0.44(\mathrm{P}<0.001)$.

Keywords: Buffalo, Bubalus bubalis; Gas changes, Summer period; Milk yield; Feed intake

\section{Introduction}

Gas changes occurring in the shelter and indoor environmental conditions, in general, are important parameters that affect animal health and performance. In recent years, many studies have been conducted on examining the effects of indoor gas density and environmental conditions on feed intake and milk yield (Johnson 1985; Du Preez et al. 1990; Brose et al. 1998; Jungbluth et al. 2001; Bouraoui et al. 2002; Snell et al. 2003; Zhang et al. 2005; Zhao et al. 2007; Zhang et al. 2007 and Bjorneberg et al. 2009). It has been reported that in-house temperature and gas changes affect milk yield in cows. As a matter of fact, at high temperatures, the milk yield was decreased by 10-50\% (McDowell et al. 1976; West et al. 2003 and Fournel et al. 2017). Fertility is also negatively affected and the conception rate could be decreased by 20-30\% (De Rensis and Scaramuzzi 2003).

According to Steevens \& Ricketts (1993), feed intake and milk yield of dairy cattle were significantly decreased at temperatures above $27^{\circ} \mathrm{C}$. Appropriate temperatures for buffaloes are within $10-27^{\circ} \mathrm{C}$ (Schein \& Hafez 1969). At the same time, the relative humidity in the shelter should be between 55-75\% (Bickert 2001). Although buffaloes live in tropical areas, they are very sensitive to changing climatic conditions. They can be easily affected by increased temperature and humidity values (Degirmencioglu et al. 2020).

While conducting studies on in-house gas levels, their effects on human and animal health have been taken into account (Maghirang and Manbeck 1993). As previously indicated, when the ammonia concentration in animal shelters exceeds 50-60 ppm, feed intake and production are decreased (Alagoz et al. 1996). Moreover, when the shelter air is dry and relative humidity falls below $40 \%$, the dust from litter and manure mixtures with the air and causes infections in the respiratory tract of animals (Okuroglu \& Delibas 1986). In terms of occupational health and safety, in the country legislation, ammonia exposure limit values are 20 ppm for 8 hours (TWA) exposure, 50 ppm for 15 minutes (STEL) exposure, and carbon dioxide is 5000 ppm (Sainsbury 1981). Bayhan (1996) stated that the carbon dioxide concentration in the barn should not exceed 3300 ppm and the ammonia concentration should not exceed 20 ppm. 
The present study aiming at the observation of the effects of changes in the environmental conditions inside the shelter on milk yield and dry matter intake in buffaloes. For this purpose, 24-hour continuous measurements were recorded for 4 days in the summer season at the buffalo shelter. Indoor environmental conditions such as $\mathrm{NH}_{3}, \mathrm{CH}_{4}$, and $\mathrm{CO}_{2}$ gas concentrations and temperature, wind, and relative humidity were determined in the buffalo barn.

\section{Material and Methods}

\subsection{Study site}

Building materials such as sand, briquettes, and cement are used for the construction of shelter walls and bedding. Eternite roof is widely used for the cover of the roofs. There are $20 \mathrm{~cm}$ air inlets between the sidewalls and under the eaves.

The chimney height on the roof is $4 \mathrm{~m}$. The length of the stall is $200 \mathrm{~cm}$, the width of the stall is $116 \mathrm{~cm}$, the height of the bar is $100 \mathrm{~cm}$. Feeder path, width, and depth are also determined as $90 \mathrm{~cm}, 60 \mathrm{~cm}$, and $40 \mathrm{~cm}$ respectively. When the barn size of the enterprise was examined; length, width, and height values were obtained as $20 \mathrm{~m}, 8 \mathrm{~m}$, and $3 \mathrm{~m}$ respectively. Two windows are facing each other on the sidewalls of the shelter. The windows are rectangular and $60 \mathrm{~cm}$ high. Fertilizers accumulated in the shelter are transferred to the manure pit with a shovel.

The barn ventilation in the enterprise is provided by natural ventilation. The trial is planned in a semi-open barn system with a capacity of 20 milking buffalo cows. The barn stall design is a two-row structure. The buffaloes are taken to the birth chambers between January and February, and the calves (malaks) are kept in a two-month feeding program after birth. AWB (Anatolian Water Buffalo) (5 and 6 years old) at stage 50-60 days of lactation are randomly selected.

According to the 40-year average values in Bursa City, it is stated that the dominant wind direction is southwest and north direction in the first degree and be the south direction in the second degree In the same report, average wind speeds were obtained as 2.1 and $1.5 \mathrm{~m} / \mathrm{sec}$, respectively (Anonymous 2016).

This study was carried out on a buffalo farm in Karaoglan village of Mustafakemalpasa district (40 $05^{\prime} 17^{\prime \prime}$ N, 28 $30^{\prime} 53^{\prime \prime}$ E) as shown in Figure 1.

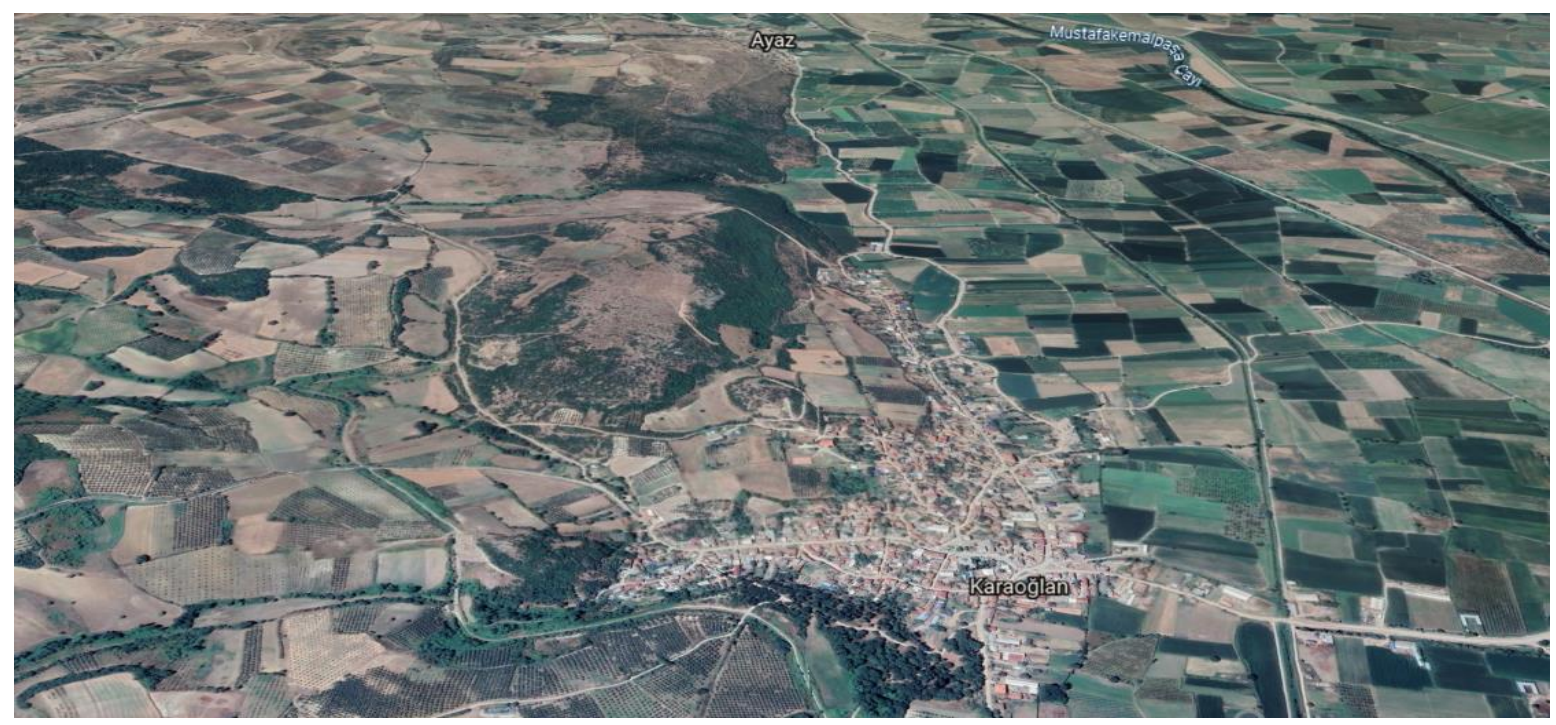

Figure 1- Location of Karaoglan District (Google Earth 2021)

\subsection{Nutrition regime and milking of buffaloes}

Alfalfa was provided at 6:00 a.m., and silage was offered once a day at 7:00 p.m. The buffaloes in the trial had free access to water and pasture. At the end of the study, the individual feed intake of buffalo cows was determined daily, taking into account the reports of Maynet and Gordon (1984). DMI was determined at the end of the sample collection period by weighing the offered diet and remnants from the previous day. Pasture intake cannot be measured since animals had free access to it. The animals were milked twice a day at 6:00 a.m. and 7:00 p.m. The concentrate feed mixture (CFM) consisted of 33\% barley, 34\% wheat, $31 \%$ sunflower meal, $1 \%$ marble powder, $0.75 \%$ salt and $0.25 \%$ vitamin+mineral mix. During the trial, all buffaloes were provided with corn silage $\left(15 \mathrm{~kg} \mathrm{day}^{-1}\right)$, alfalfa hay $\left(6 \mathrm{~kg} \mathrm{day}^{-1}\right)$, and $0.70 \mathrm{~kg}$ of the CFM (per $1.0 \mathrm{~kg}$ of milk per day) (193.9 $\mathrm{g}$ $\mathrm{CP}$ and $\left.2830 \mathrm{kcal} \mathrm{ME} \mathrm{kg} \mathrm{DM}^{-1}\right)$ as shown in Table 1. Determination of CP was implemented according to the Association of Official Analytical Chemists (AOAC 1990) and that of fiber fractions (NDF and ADF) according to Van Soest et al. (1991). The 
metabolizable energy value of the diet was calculated based on chemical analyses using computer software from the National Research Council (NRC 2001).

Table 1- Composition of feed mixture and roughages fed by experimental buffaloes

\begin{tabular}{|c|c|c|c|}
\hline \multirow[b]{2}{*}{ Ingredient Composition } & \multicolumn{3}{|c|}{ Roughages for buffaloes } \\
\hline & $\begin{array}{l}\text { Concentrate Feed } \\
\text { Mixture }\end{array}$ & Alfalfa hay & Corn silage \\
\hline Barley, $\mathrm{g} \mathrm{kg}^{-1}$ & 330 & & \\
\hline Wheat, $\mathrm{g} \mathrm{kg}^{-1}$ & 340 & & \\
\hline Sunflower meal, $\mathrm{g} \mathrm{kg}^{-1}$ & 310 & & \\
\hline Marble powder, $\mathrm{g} \mathrm{kg}^{-1}$ & 10 & & \\
\hline Salt, $\mathrm{g} \mathrm{kg}^{-1}$ & 7.5 & & \\
\hline Vitamin+minerals ${ }^{1}, \mathrm{~g} \mathrm{~kg}^{-1}$ & 2.5 & & \\
\hline Total & 1000 & & \\
\hline \multicolumn{4}{|l|}{ Nutrient composition } \\
\hline $\mathrm{DM}^{2}, \mathrm{~g} \mathrm{~kg}-1$ & 887.0 & 894.4 & 310.3 \\
\hline $\mathrm{OM}, \mathrm{g} \mathrm{kg}^{-1}$ & 850.7 & 803.8 & 261.1 \\
\hline $\mathrm{CP}, \mathrm{g} \mathrm{kg}^{-1}$ & 193.9 & 146.5 & 66.2 \\
\hline $\mathrm{EE}, \mathrm{g} \mathrm{kg}^{-1}$ & 19.4 & 15.2 & 23.2 \\
\hline CELL, $\mathrm{g} \mathrm{kg}^{-1}$ & 114.2 & 330.4 & 190.0 \\
\hline $\mathrm{CA}, \mathrm{g} \mathrm{kg}^{-1}$ & 36.3 & 90.6 & 49.2 \\
\hline NFE, $\mathrm{g} \mathrm{kg}^{-1}$ & 523.2 & 311.7 & 18.2 \\
\hline Starch, $\mathrm{g} \mathrm{kg}^{-1}$ & 332.0 & 20.0 & 218.1 \\
\hline $\mathrm{NDF}, \mathrm{g} \mathrm{kg}^{-1}$ & 220.0 & 409.9 & 428.6 \\
\hline $\mathrm{ADF}, \mathrm{g} \mathrm{kg}^{-1}$ & 174.0 & 370.4 & 307.2 \\
\hline ADL, $\mathrm{g} \mathrm{kg}^{-1}$ & 43.0 & 90.6 & 63.2 \\
\hline $\mathrm{ME}(\mathrm{kcal} / \mathrm{kg} \mathrm{DM})^{3}$ & 2830 & 1780 & 696 \\
\hline
\end{tabular}

${ }^{1}$ Trace minerals and vitamins (per kg): $50.000 \mathrm{mg}$ Niacin; $150 \mathrm{mg} \mathrm{Co} ; 800 \mathrm{mg} \mathrm{Iyot;} 150 \mathrm{mg} \mathrm{Se} ; 50.000$ mg Mn; $50.000 \mathrm{mg}$ Fe; Zn 50.000 mg; Cu 10.000 mg; 15.000.000 IU Vitamin A; 3.000.000 IU Vitamin D3;20.000 mg Vitamin E; ${ }^{2}$ DM: Dry Matter; OM: Organic Matter; CP: Crude Protein; EE: Ether Extract; CELL: Cellulose; CA: Crude Ash; NFE: Nitrogen Free Extract; NDF: Neutral Detergent Fibre; ADF: Acid Detergent Fibre; ${ }^{3}$ ADL: Acid Detergent Lignin; ${ }^{3} \mathrm{ME}$ : Metabolizable Energy.

\subsection{Shelters}

Gas measurements were carried out with 3 gas measuring devices in 6 months and a total of 24 days of data were recorded. Temperature, relative humidity, and air velocity were measured with Testo 435 (Testo, Germany), and $\mathrm{CH}_{4}, \mathrm{NH}_{3}$, and $\mathrm{CO}_{2}$ gases were measured with MultiRAE Lite multi-gas meter (Wireless Portable Multi-Gas Monitor- RAE Systems by Honeywell, USA) to show indoor conditions and air quality indicators. In this period, to be able to determine the gas condensation in the shelters, 24-hour data records were collected with instruments hung on measurement points in the shelter (Figure 2).

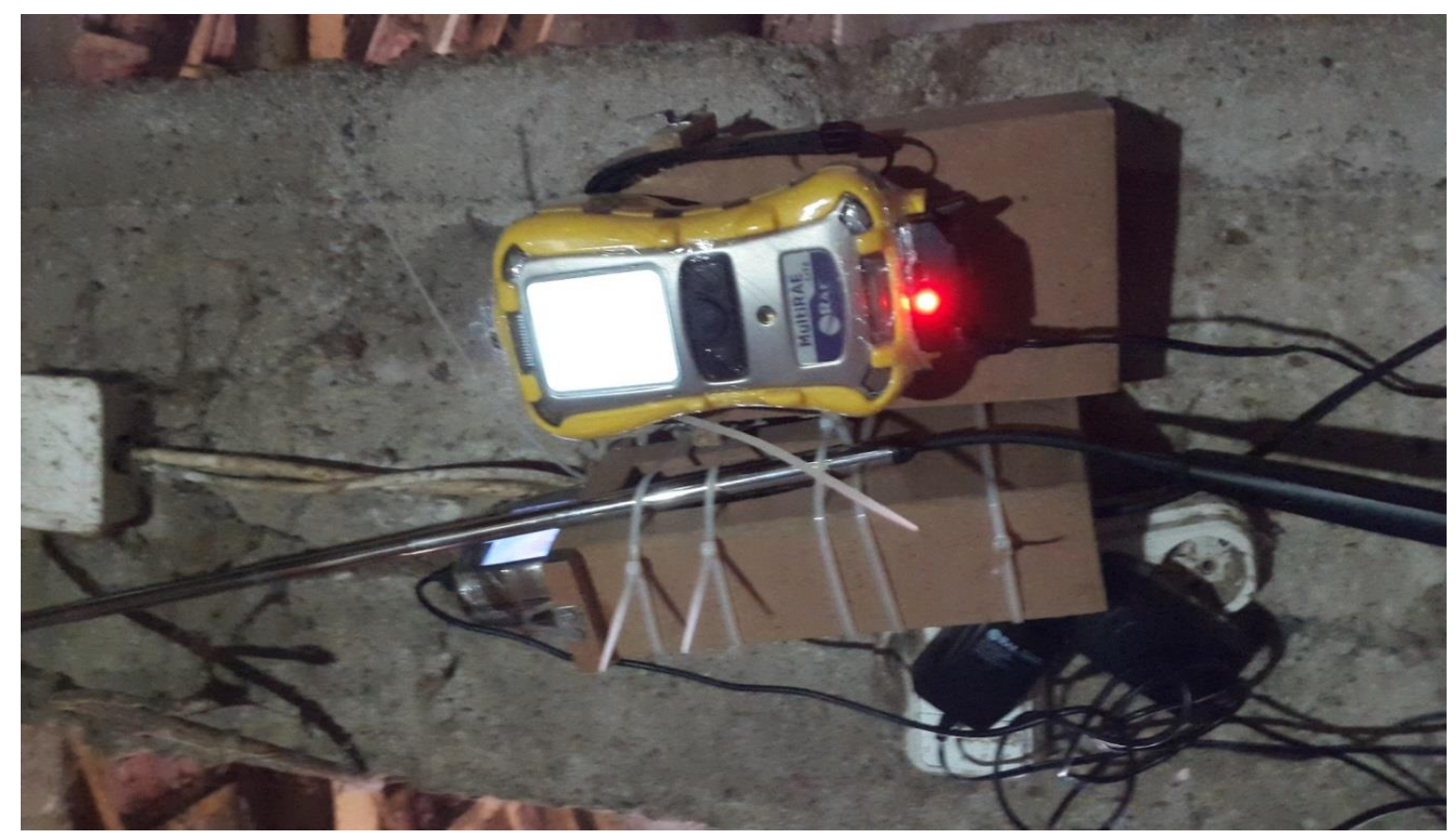

Figure 2- The general condition of measuring devices in the shelter 


\subsection{Statistical analysis}

Variance analysis was used in determining the differences between the averages of in-shelter gas measurements, and the $\mathrm{F}$ test, test in determining the significance level of the differences observed between the averages (Turan 1995). Models were developed for the changes in gas concentration and indoor temperature and humidity in the buffalo shelter and multivariate regression analysis was applied. The linear regression method, which is the SPSS (2006) automatic regression determination system was used.

\section{Results and Discussion}

The daily average and maximum indoor $\mathrm{CH}_{4}, \mathrm{NH}_{3}$, and $\mathrm{CO}_{2}$ gas concentrations are shown in Table 2.

As indicated in Table 2, methane concentrations increased from May to August as a result of temperature enhancement in the buffalo shelters. In March and April, no measurement was recorded because $\mathrm{CH}_{4}$ concentrations were below the measurement limit value of the device. When the gas production results of methane are examined, the highest value was obtained in August with $7.12 \pm 0.15 \%$. The other values were $4.88 \pm 0.13 \%$ for July, $3.72 \pm 0.09 \%$ for June, and $1.32 \pm 0.30 \%$ for May. Differences between all means were found to be statistically significant $(\mathrm{P}<0.05)$. As observed in Table 2, the average ammonia production value in the shelter of buffaloes during the experimental period varied between $11.12 \pm 0.42$ and $2.40 \pm 0.18$ (ppm). The highest average ammonia value in the shelter was obtained in August, followed by July, June, May, April, and March. Differences were found to be statistically significant $(\mathrm{P}<0.05)$. As reported in Table 2, the average $\mathrm{CO}_{2}$ levels inside the shelter of buffaloes during the experimental period varied between $620 \pm 14.14$ and $1196 \pm 40.61 \mathrm{ppm} ; \mathrm{CO}_{2}$ values were the highest in August and the lowest in March. It was observed that the differences among months in terms of $\mathrm{CO}_{2}$ concentrations were statistically significant $(\mathrm{P}<0.05)$. The temperature inside the shelter has increased continuously throughout the experimental period from $15.60 \pm 0.08$ to $28.15 \pm 0.28\left({ }^{\circ} \mathrm{C}\right)$, with the highest temperature detected in August and the lowest in March. It was observed that the differences observed among months were statistically significant $(\mathrm{P}<0.05)$. As presented in Table 2 , the humidity values in buffalo shelters varied between 49.08 \pm 3.023 and 75.57 $\pm 0.74(\%)$. Humidity was the highest in March and the lowest in August (P<0.05). Finally, air velocity recorded in the buffalo barn varied between $0.157 \pm 0.08$ and $0.025 \pm 0.03$.

Table 2- Gas concentrations measured in the buffalo shelter during the summer period ( $m e a n \pm S E)$

\begin{tabular}{lllllll}
\hline \multirow{2}{*}{ Buffalo shelter } & $\begin{array}{l}\text { March } \\
\overline{\mathrm{X}} \pm \mathrm{S}_{\overline{\mathrm{x}}}\end{array}$ & $\begin{array}{l}\text { April } \\
\overline{\mathrm{X}} \pm \mathrm{S}_{\overline{\mathrm{x}}}\end{array}$ & $\begin{array}{l}\text { May } \\
\overline{\mathrm{X}} \pm \mathrm{S}_{\overline{\mathrm{x}}}\end{array}$ & $\begin{array}{l}\text { June } \\
\overline{\mathrm{X}} \pm \mathrm{S}_{\overline{\mathrm{x}}}\end{array}$ & $\begin{array}{l}\text { July } \\
\overline{\mathrm{X}} \pm \mathrm{S}_{\overline{\mathrm{x}}}\end{array}$ & $\begin{array}{c}\text { August } \\
\overline{\mathrm{X}} \pm \mathrm{S}_{\overline{\mathrm{x}}}\end{array}$ \\
\hline $\mathrm{CH}_{4}(\%)$ & 0.00 & 0.00 & $1.32 \pm 0.30^{\mathrm{d}}$ & $3.72 \pm 0.09^{\mathrm{c}}$ & $4.88 \pm 0.13^{\mathrm{b}}$ & $7.12 \pm 0.15^{\mathrm{a}}$ \\
$\mathrm{NH}_{3}(\mathrm{ppm})$ & $2.40 \pm 0.18^{\mathrm{e}}$ & $5.84 \pm 0.41^{\mathrm{d}}$ & $6.32 \pm 0.20^{\mathrm{c}}$ & $7.28 \pm 0.60^{\mathrm{c}}$ & $9.04 \pm 0.40^{\mathrm{b}}$ & $11.12 \pm 0.42^{\mathrm{a}}$ \\
$\mathrm{C}_{2}(\mathrm{ppm})$ & $620 \pm 14.14^{\mathrm{c}}$ & $632 \pm 18.90^{\mathrm{c}}$ & $644 \pm 13.01^{\mathrm{c}}$ & $676 \pm 10.45^{\mathrm{c}}$ & $920 \pm 42.81^{\mathrm{b}}$ & $1196 \pm 40.61^{\mathrm{a}}$ \\
$\mathrm{T}\left({ }^{\circ} \mathrm{C}\right)$ & $15.60 \pm 0.08^{\mathrm{d}}$ & $20.92 \pm 0.49^{\mathrm{c}}$ & $24.44 \pm 0.35^{\mathrm{b}}$ & $25.84 \pm 0.28^{\mathrm{b}}$ & $27.63 \pm 0.18^{\mathrm{a}}$ & $28.15 \pm 0.28^{\mathrm{a}}$ \\
$\mathrm{V}(\mathrm{m} / \mathrm{s})$ & $0.157 \pm 0.08^{\mathrm{a}}$ & $0.133 \pm 0.01^{\mathrm{b}}$ & $0.137 \pm 0,09^{\mathrm{b}}$ & $0.047 \pm 0.04^{\mathrm{c}}$ & $0.060 \pm 0.05^{\mathrm{c}}$ & $0.025 \pm 0.03^{\mathrm{d}}$ \\
$\mathrm{RH}(\%)$ & $75.92 \pm 0.74^{\mathrm{a}}$ & $67.74 \pm 2.13^{\mathrm{b}}$ & $67.87 \pm 2.15^{\mathrm{b}}$ & $64.80 \pm 2.15^{\mathrm{bc}}$ & $59.96 \pm 2.78^{\mathrm{c}}$ & $49.07 \pm 3.02^{\mathrm{d}}$ \\
$\mathrm{TDMC}\left(\mathrm{kg} \mathrm{d}^{-1}\right)$ & $11.00 \pm 0.12^{\mathrm{d}}$ & $11.60 \pm 0.10^{\mathrm{c}}$ & $12.50 \pm 0,09^{\mathrm{b}}$ & $13.20 \pm 0.06^{\mathrm{a}}$ & $12.30 \pm 0.14^{\mathrm{b}}$ & $11.50 \pm 0,15^{\mathrm{c}}$ \\
$\begin{array}{l}\text { The milk yield } \\
\left(\mathrm{kg} \mathrm{d}^{-1}\right)\end{array}$ & $4.90 \pm 0.07^{\mathrm{c}}$ & $5.50 \pm 0.97^{\mathrm{b}}$ & $6.67 \pm 0.027^{\mathrm{a}}$ & $6.30 \pm 0.06^{\mathrm{a}}$ & $6.00 \pm 0.07^{\mathrm{b}}$ & $5.45 \pm 0.09^{\mathrm{bc}}$ \\
\hline
\end{tabular}

$\mathrm{CH}_{4}$; average Methane, $\mathrm{NH}_{3}$; average ammonia, $\mathrm{CO}_{2}$; average Carbon dioxide, T; average temperature, $\mathrm{V}$; air velocity, $\mathrm{RH}$; average humidity, TDMC; average total dry matter consumption, $\mathrm{a}-\mathrm{b}, \mathrm{c}-\mathrm{d}:(\mathrm{P}<0.05)$ Different letters in the same line are significantly different.

It was determined that the gas concentration data obtained in the present study remained at normal values when compared with the literature. As indicated, the highest values for methane concentration were found during the summer period. Bjorneberg et al. (2009) confirm these findings since the $\mathrm{CH}_{4}$ concentration in the compartments increased in June and September compared to January and March in their experiment. Controversial findings have emerged in studies conducted with ammonia during the summer period, and it has been reported that these discrepancies could be possibly attributed to the environmental conditions inside the shelter. Indeed, the researchers reported ammonia values within the shelter from 5.3 ppm (Jungbluth et al. 2001), 1.47 ppm (Zhao et al. 2007 \& Zhang et al. 2007) to 8.2 ppm (Snell et al. 2003).

The $\mathrm{CO}_{2}$ and $\mathrm{NH}_{3}$ concentrations in the buffalo shelter recorded during the experimental period varied between $620-1200$ and 2.40-11.10 ppm, respectively. According to the previous literature, values for $\mathrm{CO}_{2}$ and $\mathrm{NH}_{3}$ were within the normal limits (3300-5000 and 20-50 ppm, respectively) (Brose et al. 1998; Jungbluth et al. 2001) and can be considered as not dangerous for animal and human health.

The wide range of gas concentrations could be possibly attributed to the different manure removal systems applied in the shelters, the duration of the manure in the shelter, the different ventilation systems of the shelters, the different rationed proteins 
given to the animals, and the structural differences of the shelters (Snell et al. 2003; Ndegwa et al. 2008; Zhang et al. 2008; Merino et al. 2008; Angel et al. 2008).

As can be observed in Table 2 and Figure 3, the total dry matter intake (TDMI) of buffaloes increased continuously until mid-summer. It was determined that TDMI varied between $11.00 \pm 0.12$ and $13.20 \pm 0.06 \mathrm{~kg}$ during the experimental period. Water buffaloes had the highest feed intaken $(13.20 \mathrm{~kg})$ in June due to their lactation stage. However, the feed intake of buffaloes decreased as an effect of the increase in air temperature. It was observed that the differences observed among months in terms of feed intake were statistically significant $(\mathrm{P}<0.05)$. Although the milk yield of buffalo was low in March $(4.90 \pm 0.07)$, increased in April (5.50 \pm 0.97$)$. The milk yield of buffalo showed a linear increase and reached the highest level of $6.67 \pm 0.027$ in May. Afterward, the milk yield of buffaloes was decreased. The temperature increase in July and August further accelerated the decline in milk yield. It was observed that the difference observed among months in terms of milk yield was also statistically significant $(\mathrm{P}<0.05)$. It can be concluded that this decrease is the result of the increase in ambient temperature, the increase in temperature caused by the breakdown of nutrients in the body, triggering heat stress in the buffaloes and the resulting reduction in feed intake, leading to insufficient ingestion of nutrients for milk synthesis (Degirmencioglu 2020). In addition to this, sudden temperature changes are thought to cause the aforementioned implications, as well as a decrease in the endocrine system function (endocrine glands) (Gantner et al. 2011). The findings obtained from the present research regarding the dry matter intake and milk yield as a result of the in-house gas densities in buffaloes are consistent with the findings of previous researchers (West et al. 2003; Fournel et al. 2017).

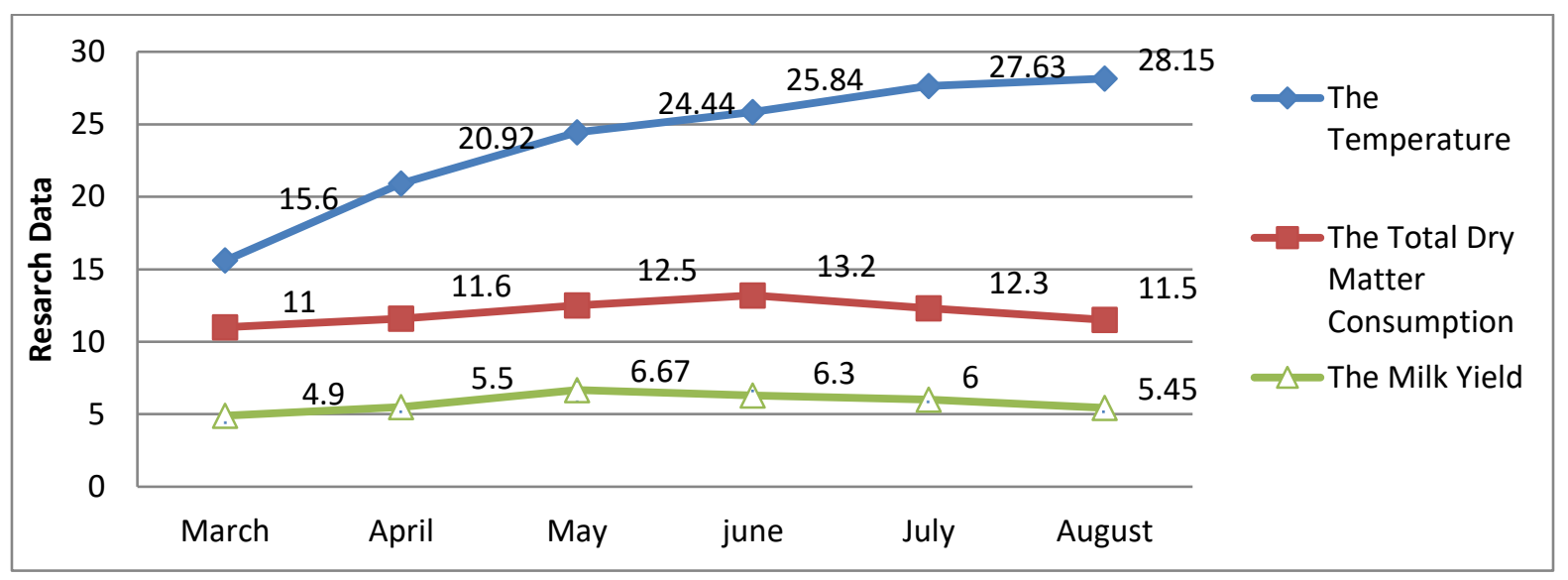

Figure 3- The Effects of Temperature Changes in Shelter on Dry Matter Consumption and Milk Yield

Monitoring the environmental conditions and gas concentration changes in the shelter is important in terms of controlling the health and productivity of the animals. The gas exchange model in the buffalo shelter is shown in Table 3. As indicated, while there is a negative interaction between humidity and indoor temperature in a buffalo shelter, there is a positive interaction between $\mathrm{CO}_{2}, \mathrm{CH}_{4}$, and $\mathrm{NH}_{3}$ concentrations and indoor temperature.

Table 3- Gas exchange model in the buffalo shelter

\begin{tabular}{llllll}
\hline Parameter & Polluting & Regression equation & $R$ & $R^{2}$ & $P$ \\
& $R H$ & $92.470-1.188 T^{*}$ & -0.40 & 0.16 & 0.00 \\
\hline & $\mathrm{NH}_{3}$ & $1.388+0.399 \mathrm{~T}^{* *}-0.49 \mathrm{RH}^{*}-7.483 \mathrm{~V}$ & 0.76 & 0.57 & 0.00 \\
& $\mathrm{CH}_{4}$ & $-2.940+0.351 \mathrm{~T}^{* *}-0.021 \mathrm{RH}-12.659 \mathrm{~V}^{* *}$ & 0.86 & 0.73 & 0.00 \\
& $\mathrm{CO}_{2}$ & $77.744+29.602 \mathrm{~T}^{* *}$ & 0.55 & 0.29 & 0.00 \\
\hline The milk yield $\left(\mathrm{kg} \mathrm{d}^{-1}\right)$ & $\mathrm{T}\left({ }^{\circ} \mathrm{C}\right)$ & $4.257+0.065 \mathrm{~T}^{* * *}$ & 0.44 & 0.19 & 0.00 \\
& $\mathrm{RH}$ & $6.011-0.03 \mathrm{RH}$ & 0.06 & 0.04 & 0.44 \\
& $\mathrm{~T} \mathrm{RH}$ & $3.60+0.074 \mathrm{~T}^{* * *}+0.07 \mathrm{RH}$ & 0.46 & 0.21 & 0.00 \\
$<25\left({ }^{\circ} \mathrm{C}\right)$ & & $2.074+0.658 \mathrm{TDMC}^{* *}$ & 0.77 & 0.59 & 0.00 \\
$25>\left({ }^{\circ} \mathrm{C}\right)$ & & $1.724+0.347 \mathrm{TDMC}^{* *}$ & -0.54 & 0.29 & 0.00 \\
$\mathrm{TDMC}\left(\mathrm{kg} \mathrm{d}^{-1)}\right.$ & $\mathrm{T}\left({ }^{\circ} \mathrm{C}\right)$ & $9.901+0.089 \mathrm{~T}^{* *}$ & 0.44 & 0.19 & 0.00 \\
\hline
\end{tabular}

T: Temperature; RH: humidity (\%); $\mathrm{NH}_{3}$; ammonia, $\mathrm{CH}_{4}$; methane, V: air velocity $(\mathrm{m} / \mathrm{s}) \mathrm{TDMC}$; total dry matter consumption $* \mathrm{P}<0.05$, **P<0.01

This interaction was statistically significant $(\mathrm{P}<0.01)$. The fact rise in the temperature increases the $\mathrm{NH}_{3}$ release supports the findings of Zhang et al. (2005). On the other hand, K1lic (2011) stated that there is a negative interaction between other gas concentrations other than $\mathrm{CO}_{2}$ and indoor temperature in dairy cattle barns. In our study, it was determined that there is a negative interaction between $\mathrm{CH}_{4}$ and $\mathrm{NH}_{3}$ concentrations and humidity and air velocity in buffalo shelters, with the inverse relationship between $\mathrm{NH}_{3}$ concentration and humidity being statistically significant $(\mathrm{P}<0.05)$. The results obtained by Zhang et al. $(2008)$ support that $\mathrm{CH}_{4}$ and $\mathrm{NH}_{3}$ emissions can be reduced by properly designed ventilation systems in animal shelters. The regression equation between humidity and temperature was determined as $\mathrm{Y}=92.470-1.188 \mathrm{~T}$, regression coefficient $\left(\mathrm{R}^{2}\right) 0.16$ and 
correlation coefficient $(\mathrm{r})-0.40(\mathrm{P}<0.001)$. There is an inverse and moderate relationship between them. The coefficients calculated in this study are below the values obtained by Turkmen (2018) $\left(\mathrm{R}^{2}=95.36\right.$ and $\left.\mathrm{r}=-0.98\right)$. The multiple regression equation between ammonia and temperature, humidity and air velocity in the studied buffalo shelter was $\mathrm{Y}=1.388+0.399 \mathrm{~T} * *$ $-0.49 \mathrm{RH} *-7.483 \mathrm{~V}, \mathrm{R}^{2}=0.57$ and $\mathrm{r}=0.57(\mathrm{P}<0.001)$.

Regression equation between methane and temperature, humidity, and air velocity was $\mathrm{Y}=-2.940+0.351 \mathrm{~T} * *-0.021 \mathrm{RH}-$. $12.659 \mathrm{~V} * *, \mathrm{R}^{2}=0.73$ and $\mathrm{r}=0.86(\mathrm{P}<0.001)$.

Regression equation between milk yield and temperature in buffaloes was $\mathrm{Y}=4.257+0.065 \mathrm{~T} * *, \mathrm{R}^{2}=0.19$ and $\mathrm{r}=0.44$ $(\mathrm{P}<0.001)$. The coefficients calculated in this relationship are lower than the values calculated by Turkmen $(2018)\left(\mathrm{R}^{2}=66.2 \%\right.$ and $\mathrm{r}=0.74)$. On the other hand, although the temperature rise increased the milk yield, a decrease of $370 \mathrm{~mL}$ was detected in milk yield after May. The regression equation between milk yield and relative humidity was $\mathrm{Y}=6.011-0.03 \mathrm{RH}$ and showed a low degree of interaction.

Even at the highest humidity of 75.92\% in March, the continuation of milk and feed intake of buffaloes was due to its harmony with nature and ability to endure hardships.

The multiple regression equation between milk yield and temperature, humidity and air velocity in the studied buffalo shelter is $\mathrm{Y}=3.60+0.074 \mathrm{~T} * *+0.07 \mathrm{RH}, \mathrm{R}^{2}=0.21$ and $\mathrm{r}=0.46(\mathrm{P}<0.001)$. As variables, it had a positive effect with 0.074 coefficient in temperature and 0.07 coefficient in humidity.

As regression equality between milk yield and total dry matter intake at temperatures below $25{ }^{\circ} \mathrm{C}$ in buffaloes is $\mathrm{Y}=2.074$ +0.658 TDMI, $\mathrm{R}^{2}=0.59$ and $\mathrm{r}=0.77$. They showed a moderate interaction $(\mathrm{P}<0.001)$. Regression equation between milk yield in buffaloes and total dry matter consumption at temperatures above $25^{\circ} \mathrm{C}$ is $\mathrm{Y}=1.724-0.347 \mathrm{TDMI} * *, \mathrm{R}^{2}=0.29$ and $\mathrm{r}=-0.54$, so they showed a moderate inverse interaction $(\mathrm{P}<0.001)$. In the studied buffalo shelter, it was determined that regression equation between feed intake and temperature was $\mathrm{Y}=9.901+0.089 \mathrm{~T} * *, \mathrm{R}^{2}=0.19$ and $\mathrm{r}=0.44(\mathrm{P}<0.001)$. Basically, for an increase of $+1{ }^{\circ} \mathrm{C}$ in air temperature, a $0.50 \mathrm{~kg}$ decrease in dry matter intake and a decrease of $264 \mathrm{ml}$ in milk yield occurred. West et al. (2003) partially support the previous findings stating that the DM intake of cows decreased by $0.85 \mathrm{~kg}$ in case of an increase of $1{ }^{\circ} \mathrm{C}$ in air temperature. It can be concluded that the water buffaloes are less exposed to heat stress because they enter the pond to cool off and the gas density decreases with the manure cleaning and natural ventilation provided in the shelter, compared to dairy cows. Fournel et al. (2017) support the hypothesis that the decrease in feed intake and milk yield can be confined by reducing the temperature and humidity index of dairy cattle in open animal shelters where airflow is provided by the panel and basket-type fans.

\section{Conclusions}

Generally, it has been determined that in-barn temperature values reduce the feed intake and milk yield of buffaloes. For this purpose, positive contributions can be made to feed intake and milk yield in buffalo farms by installing fans especially throughout the feeder. It has been observed that in the in-house gas exchanges, the airflow is partially effective in reducing the level of methane, humidity, and ammonia. In hot weather, due to fact that long walks increase thermal stress for buffaloes, freeride areas and shower systems should be included outside the shelter.

\section{References}

AOAC (1990). Official methods of analysis. 15 ${ }^{\text {th }}$ ed. Assoc. Off. Anal Chem. Arlington, VA, USA. (73)1: 189-191. https://doi.org/10.1093/jaoac/73.1.189 Angel R., Powers W \& Applegate T (2008). Diet impacts for mitigating air emissions from poultry. Livestock Environment VIII. 31 August 4 September 2008, Iguassu Falls, Brazil. https://doi.org/10.13031/2013.25514

Anonymous 2016. Report of the General Directorate of Meteorology of the Republic of Turkey (In Turkish), http://www1.mgm.gov.tr/FILES/resmi-istatistikler/Turkiye-Ortalama-Ruzgar.pdf (Accessed: 12.11.2020).

Alagoz T, Kumova Y, Atilgan A \& Akyuz A (1996). A Study on the wastes generated in Livestock Facilities and the negative effects of these wastes on the Environment

Agricultural-Environmental Relations Symposium, 13-15 May 1996, M.Ü. Faculty of Engineering, Mersin (In Turkish)

Bayhan A K (1996). A Research on Mechanization Status, Problems, and Solutions of Livestock Cattle in Erzurum Region. Ph.D. Thesis, Atatürk University, Institute of Science and Technology, Department of Agricultural Mechanization, Erzurum (Published inTurkish)

Bouraoui R, Lahmar M, Majdoub A, Djemali M \& Belyea R (2002). The relationship of the temperature-humidity index with milk production of dairy cows in a Mediterranean climate. Animal Research 51(6): 479-491. https://doi.org/10.1051/animres:2002036

Brose G, Hartung E \& Jungbluth T (1998). Influences on and measurement of ammonia and greenhouse gas emissions from dairy houses. AgEng Oslo 98, E-054.

Bjorneberg D L, Leytem A B, Westermann D T, Griffiths P R, Shao L \& Pollard M J (2009). Measurement of atmospheric ammonia, methane and nitrous oxide at the concentrated dairy production facility in southern Idaho using open-path FTIR spectrometry. Transaction of ASABE, 52(5): 1749-1756. https://doi.org/10.13031/2013.29137

Bickert W G (2001). Ventilation and animal health. Agricultural Engineering Newsletter. Michigan State University

De Rensis F \& Scaramuzzi R J (2003). Heat Stress and Seasonal Effects on Reproduction in the Dairy Cow-A Review. Theriogenology, (60)6:1139-1151. https://doi.org/10.1016/s0093-691x(03)00126-2 
Degirmencioglu T (2020). Possibilities to Reduce Thermal Stress in Water Buffalo [Bubalus bubalis (Linnaeus, 1758)] Anadolu. J. of AARI, 30(1): 117-123. https://doi.org/10.18615/anadolu.727123

Du Preez J H, Hatting P I, Giesecke W H \& Eisenberg B E (1990). Heat stress in dairy cattle and other livestock under Southern African conditions. III. Monthly temperature-humidity index mean values and their significance in the performance of dairy cattle. Onderstepoort J. Vet. Res 57: 243-248

Fournel S, Ouellet V \& Charbonneau E (2017). Practices for alleviating heat stress of dairy cows in humid continental climates: A literature review Animals. 7(12):37. https://doi.org/10.3390/ani7050037

Gantner V, Mijić P, Kuterovac K, Solić D \& Gantner R (2011). Temperature-humidity index values and their significance on the daily production. Daily production of dairy cattle, Mljekarstvo. 61(1): 56-63

Johnson H D (1985). Physiological responses and productivity of cattle, Stress physiology in livestock. Basic principles, Vol. 1, CRC Press, Boca Raton, Florida pp. 4-19

Jungbluth T, Hartung E \& Brose G (2001). Greenhouse gas emissions from animal houses and manure stores. Nutrient Cycling in Agroecosystems. 60: 133-145. https://doi.org/10.1023/a:1012621627268

Kilıc I (2011). Characterization of air pollutants in animal barns. Ph.D. Thesis. Uludag University Graduate School of Natural and Applied Sciences Department of Biosystem Engineering. 202 pages. (Published inTurkish)

Maghirang R G \& Manbeck H B (1993). Dust, Ammonia, and carbon dioxide emission from a poultry house. ASAE. St Joseph. Michigan.Paper No. 93-4056

Maynet C S \& Gordon F J (1984). The Effect of Type of Concentrate and Level of Concentrate Feeding on Milk Production. Anim. Sci. 39(1): 65- 76. https://doi.org/10.1017/s0003356100027628

Merino P, Arriaga, Salcedo G, Pinto M \& Calsamiglia S (2008). Dietary modification in dairy cattle: field measurement to assess the effect on ammonia emissions in the Basque Country. Agriculture, Ecosystems and Environment. 123: 88-94. https://doi.org/10.1016/j.agee.2007.05.003

McDowell R E, Hooven N W \& Camoens J K (1976). Effects of climate on performance of Holsteins in the first lactation. J. Dairy Sc.i 59(5): 965-971. https://doi.org/10.3168/jds.s0022-0302(76)84305-6

NRC (2001). Nutrient requirements of dairy cattle. National academy press. Washington.D.C341-353. https://doi.org/10.17226/9825

Ndegwa P M, Hristov A N, Arogo J \& Sheffield R E (2008). A review of ammonia emission mitigation techniques for concentrated animal feeding operations. Biosystems Engineering. 100(4): 453-469._https://doi.org/10.1016/j.biosystemseng.2008.05.010

Okuroglu M \& Delibas L (1986). Appropriate Environmental Conditions in Animal Shelters. Livestock Seminar. TOKB. Tokat 61 Directorate, 5-8 May (In Turkish)

Van Soest P J, Robertson J B \& Lewis B A (1991). Methods for Dietary Fiber, Neutral Detergent Fiber, and Nonstarch Polysaccharides in Relation to Animal Nutrition, Journal of Dairy Science 74(10): 3583 -3597 https://doi.org/10.3168/jds.s0022-0302(91)78551-2

Sainsbury D W B (1981). Health Problems in Intensive Animal Production.

Environmental Aspects of Housing for Animal Production, England pp. 439-454. https://doi.org/10.1016/b978-0-408-10688-7.50030-8

Schein M V \& Hafez E S E (1969). The physical environment and behavior. In: The behavior of domestic animals. Balliere Tindelland Cassel London. pp. 63-94

SPSS (2006). Statistical package for social sciences, Pc Version 15, SPSS Inc. 444 N. Michigan Avenue Chicago, USA

Steevens B, \& Ricketts R (1993). Feeding and housing dairy goats. Agricultural publication G3990. The University of Missouri.

Snell H G J, Speilt F \& Van dan Weghe H F A (2003). Ventilation rates and gaseous emissions from naturally ventilated dairy houses. Biosystems Eng. 86(1): 67-73. https://doi.org/10.1016/s1537-5110(03)00113-2

Turan Z M (1995). Research and Experimental Methods. U. Univ. Zir. fac. Lecture Notes, Bursa, No: 62. 121p. (In Turkish).

Turkmen E (1998). A research on the investigation of dairy farms supported with European union instrument for pre-accession assistance-rural development (ipard) in terms of animal welfare. Ph.D. Thesis. Uludag University Graduate School of Natural and Applied Sciences Department of Biosystems Engineering, 148 pages. (Published inTurkish)

West J W, Mullinix B G \& Bernard J K (2003). Effects of hot, humid weather on milk temperature, dry matter intake, and milk yield of lactating dairy cows. Journal of Dairy Science $86: 232-242$

Zhang G, Strøm JS, Li B Rom H B, Morsing S, Dahl P \& Wang C (2005). Emission of ammonia and other contaminant gases from naturally ventilated dairy cattle Buildings. Biosystems Engineering, 92(3): 355-364. https://doi.org/10.1016/j.biosystemseng.2005.08.002_

Zhang Q, Zhou X J, Cicek N \& Tenuta M (2007). Measurement of odor and greenhouse gas emissions in two swine farrowing operations. Canadian Biosys.Eng. 49: 13-20

Zhang G, Bjerg B, Strøm J S, Morsing S, Kai P, Tong G \& Ravn P (2008). Emission effects of three different ventilation control strategies A scale model study. Biosystems Engineering 100(1): 96-104. https://doi.org/10.1016/j.biosystemseng.2008.01.012

Zhao L Y, Brugger M F, Manuzan R B, Arnold G \& Imerman E (2007). Variations in the air quality of new Ohio dairy facilities with natural ventilation systems. Appl. Engineering in Agriculture 23(3): 339-346. https://doi.org/10.13031/2013.22684

(C) 2022 by the author(s). Published by Ankara University, Faculty of Agriculture, Ankara, Turkey. This is an Open Access article distributed under the terms and conditions of the Creative Commons Attribution (CC BY) license (http://creativecommons.org/licenses/by/4.0/), which permits unrestricted use, distribution, and reproduction in any medium, provided the original work is properly cited. 